\title{
The Effect of Coronavirus (Covid19) Outbreak on Education Systems: Evaluation of Distance Learning System in Turkey
}

\author{
Enes BELTEKIN ${ }^{1} \&$ İhsan KUYULU ${ }^{2}$ \\ ${ }^{1,2}$ Physical Education and Sport School, Bingol University, Bingol, Turkey \\ Correspondence: Enes BELTEKİN, Physical Education and Sport School, Bingol University, Bingol, Turkey. \\ E-mail: ens_bltkn@hotmail.com
}

Received: May 7, 2020 Accepted: June 10, 2020 Online Published: June 19, 2020

doi:10.5539/jel.v9n4p1 URL: https://doi.org/10.5539/jel.v9n4p1

\begin{abstract}
Due to Covid19, measures have been taken to minimize interaction, maintain social isolation, and ensure interpersonal social distance. As a result of these decisions taken by the authorities, educational activities in Turkey were suspended at first. After some time, lessons were given in the form of distance learning on digital platforms. This research was carried out to evaluate the efficiency, positive and negative aspects of the distance learning system, and its shortcomings from the viewpoints of the students. 594 students, 139 of whom are from private universities, 455 of whom are from state universities, faculties of physical sciences and sports schools, participated in the study in the 2019-2020 academic year. In the research, a survey program known as "Web-Based Instructional Attitude Scale" was used to collect data for the purpose of the research. The data obtained at the end of the research was analyzed with the SPSS 22 statistics program and the significance level was taken as 0.05 among the variables. In order to get an idea about the distribution of the data, firstly the normality of the distributions, and then the skewness and kurtosis tests were examined. According to test results, Independent Sample $\mathrm{T}$ test was performed in binary comparisons, One-Way Variance Analysis analysis in multiple comparisons, and correlation test was used to determine the relationship between variables. According to the answers given by the students who participated in the study, although they now ensured that their education activities continue without disruption; It has been determined that the courses taught in the form of distance learning are not as effective as face-to-face education, they are insufficient in terms of efficiency for students, and technical problems in the system negatively affect students' motivation to learn. As a result, no matter how practical the distance learning system is during times of crisis, it may not be as efficient as face-to-face education, and it requires more technical development and always be ready for use.
\end{abstract}

Keywords: Covid19, sports, distance learning

\section{Introduction}

Throughout history, people have struggled against wars, natural disasters, and epidemics, to survive. In these disasters, hundreds of thousands, even millions of lives were lost. States, which are created to protect people's health, security and other rights, have sometimes been the cause of or solutions to these disasters. States have to mobilize all their institutions for their nation's peace, health, and well-being. The new coronavirus (covid19), which emerged in the Wuhan province of China in December 2019 and has since spread around the world, has become the first agenda item for state institutions. The virus identified on January 13, 2020 as a result of research conducted on a group of patients with symptoms of respiratory disease (fever, cough, shortness of breath). The outbreak was initially detected in those in the seafood and animal markets in Wuhan. Then it spread from person to person and spread to other cities in Hubei province, and other provinces of the People's Republic of China and other countries of the world. Coronaviruses are a large family of viruses that can cause disease in animals or humans. In humans, several coronaviruses are known to cause respiratory infections, ranging from colds to more severe diseases such as Middle East Respiratory Syndrome (Mers) and Severe Acute Respiratory Syndrome (Sars) (https://covid19bilgi.saglik.gov.tr, 2020).

The new coronavirus (covid-19) has adversely affected many areas. Measures, such as, quarantine and curfews have been introduced in many countries in order to reduce the impact of the outbreak and to prevent people from getting infected with the virus. In countries with curfews, disruptions have occurred in many areas, such as; agriculture, industry, tourism, and education. In order to minimize losses, the official have initiated various 
practices. Education is one of the areas most affected by this virus. According to Ertürk (1973), education is the process of revealing the difference in the behavior of a person consciously, through individual experiences. Miser stated that access to information, ability to use information, and the ability to generate new information are achieved through education. Furthermore, it is vital for people and even nations to continue lifelong learning (Miser, 2002). In the light of these views and data, education can be defined as the process of changing and evaluating one's behavior in the desired direction through environmental adjustment (Sönmez, 1991). Although we are currently fightıng for our health, we have to fulfill our responsibility to think about future generations and their welfare. The peace, health, well-being, and level of development of a nation's people depend on its educated and equipped human capital. In this context, it is imperative that people's education and training must continue. Due to the epidemic, the need to maintain social distancing, various measures have been taken to prevent people from gathering in crowded environments. It is necessary to prevent disruptions in education, to avoid time loss in accessing and using information, and to keep up-to-date on technological developments to increase learning speed (Karakeçeli, 2019).

One of the areas where social distancing is most difficult to maintain is in educational institutions. Fear of disease transmission in classroom environments has caused education activities to be terminated by various countries and continued via digital platforms. With the coronavirus, the importance of distance learning has come to the fore once again; as it provides no time loss and easy access to information. According to Icten (2006), the definition of distance learning is as follows; It is an education method that has emerged as an alternative to traditionally applied education and training programs. Education activities are planned, communication and interaction between practitioners and students is specially prepared, and education is provided from a specifically developed medium to create educational environments. On digital platforms, instruction is divided into asynchronous (asynchronous or offline) and synchronous (synchronous or online). Distance learning is defined as asynchronous (asynchronous), when the student and the teacher are not in the same timeframe. The student can watch the lecture videos or read the lecture documents in the virtual environment at any time. In synchronous education, students and teachers are in different places, but the lesson is taught by coming together on a virtual platform at the same time. The teacher and the student are in mutual online communication. In synchronous education, lessons can be watched again from the recording as in asynchronous education (Arslan, 2019).

One of the countries where coronavirus has spread and effective measures have been taken is Turkey. On March 11, 2020, the first case was found in Turkey and, in response to the possibility of further spread of the virus, on March 13, 2020; schools were cancelled for a week. Then on March 23, 2020, it was decided to switch to distance learning classes. The Turkish Ministry of Higher Education has taken a number of measures in relation to this. These measures included starting Distance learning in all universities with digital facilities that are capable of Distance Learning. For universities that do not have this capacity, the pool of Open course materials was provided to all universities on 23 March, 2020. Theoretical courses in practice-based curriculums, digital facilities and distance learning methods have begun to be used, and the practical courses will be given at an appropriate future date, including the extension of the calendar year by universities. This practice and approach at the associate and undergraduate level has also been provided at the postgraduate level. Provided that it can be properly implemented, there will be no interruption in these programs; by using distance learning and digital facilities (Higher Education Institution, 2020).

There are many studies in the literature reflecting the attitudes, expectations and evaluations of students studying in higher education institutions (Begimbetova, 2015; Yadigar, 2010). Şirin (2015) investigated the attitudes of 368 first year students towards Foreign Language I courses conducted using distance learning. Similarly, Ekmekçi (2015) took both qualitative and quantitative approaches and analyzed the perceptions of 72 first year students about the Foreign Language I course. There are also studies examining the satisfaction levels of university students for distance learning courses and their readiness for distance learning courses (Çakır \& Yurtsever, 2012; Doğan \& Tatık, 2015; Iliniş, 2006; Mercan, 2018; Orhan, 2016).

Thanks to this application, which has been put forward to continue education and training, the whole process will be continued. The efficiency of this application, which is implemented by necessity, is a question mark in the minds of both educators and students. This research was carried out in order to evaluate the efficiency, the pros and cons and the missing points of the distance learning system, which has become widely used by universities in Turkey due to coronavirus.

\section{Material and method}

\subsection{Purpose and Importance of the Study}

In these days when it is understood that human health is more important than anything, social isolation and social 
distance rules are introduced in order to minimize total interaction and socialization. One of the places where the social distance is paid the least attention is the educational institutions. As a result of decisions taken by the relevant authorities in regard to education and training activities in Turkey were suspended in the first place and then switched to digital platforms through the distance learning system. This research was carried out with the aim of evaluating the efficiency, positive and negative sides and deficiencies of the distance learning system through the eyes of students. It is important research reveals the necessity of making arrangements regarding the system in order to discover the missing points of the distance learning system, which provides continuing education and training activities without interruption, and to provide more efficient and effective use of this system.

\subsection{Study Group}

A total of 594 students participated in this study in the 2019-2020 academic year, 139 of whom were private university students, 455 of whom were educated in the Faculty of Sports Sciences and higher-schools of physical education and sports of state universities. Of the students who participated in the study, $60.9 \%$ were male and $39.1 \%$ were female. Of the students who participated in the study, $30.3 \%$ were studying in the coaching department, $18.2 \%$ were studying in the physical education and sports teaching department, and $15.0 \%$ were studying in the recreation department, and $36.5 \%$ were studying in the sports management department. It was also determined that $25.6 \%$ of the students who participated in the study followed distance learning courses in a computer environment and $74.4 \%$ followed lessons by smartphone.

\subsection{Data Collection Tools}

In the research, a survey technique was used as a data collection tool. In the first part of the study, there were a total of 7 questions including the demographic information of the participants (gender, department, etc.) In the second part of the research, the "web-based teaching attitude scale", which was updated in the doctoral study by Donmuş-Kaya (2018), developed by Erdoğan et al. (2007) was used. The scale consists of 2 sub-dimensions and 26 questions, namely effectiveness and resistance. Cronbach alpha reliability coefficient of the scale was determined as .91 in the study by Donmuş-Kaya (2018). Expressions in the scale are rated as 5-point Likert.

\subsection{Statistical Analysis}

The data collected in order to examine the views of the students studying at the Faculty of sports sciences and physical education and sports schools on the transition of educational institutions to distance learning system and the efficiency of the system due to Coronavirus outbreak were analyzed and the results were interpreted with the statistical package program SPSS 22 program. Descriptive statistics including arithmetic mean, standard deviation, frequency and percentage distributions are presented to provide insight into demographic information and other group questions. In order to determine the relationship of students' views towards the distance learning system with some demographic variables, the normality of the distributions (Kolmogorov-Smirnov) and then Skewness and Kurtosis tests were examined. In the study, "normal" expression scores are individuals whose $Z$ value varies between -3 and +3 , and "extreme values" are those whose $Z$ value is outside the range of -3 and +3 (Osborne \& Amy, 2004). However, according to Shao (2002), the normal distribution of the data to be used in the study depends on the values of skewness and kurtosis between \pm 3 . Independent Sample T (Independent Sample T) and One-Way Variance Analysis (One Way Anova) tests were applied for variables that show normal distribution according to the test results. If there is a difference between the variables, Tukey HSD and Dunnet T3 tests were used according to the homogeneity results from the Post-Hoc tests to determine which group or groups originated from this difference. The results were evaluated at $95 \%$ confidence interval and significance level at $p<0.05$.

\section{Research Findings}

This section is where the statistical results of the study will be explained. Statistical analyses based on the demographic characteristics of the participants will be included. 
Table 1. The distribution and averages of the statements reflecting the opinions of the students participating in the study about the effectiveness sub-dimension in the evaluation of the distance learning system

\begin{tabular}{|c|c|c|c|c|c|c|c|c|c|c|c|}
\hline \multirow[t]{2}{*}{ Propositions of the Sub Dimension of Effectiveness } & \multicolumn{2}{|c|}{$\begin{array}{l}\text { Strongly } \\
\text { Disagree }\end{array}$} & \multicolumn{2}{|c|}{ Disagree } & \multicolumn{2}{|c|}{ Undecided } & \multicolumn{2}{|c|}{ Agree } & \multicolumn{2}{|c|}{$\begin{array}{l}\text { Strongly } \\
\text { Agree }\end{array}$} & \multirow[t]{2}{*}{$\overline{\mathrm{x}} \pm$ S.s } \\
\hline & $\mathbf{n}$ & $\%$ & $\mathbf{n}$ & $\%$ & $\mathbf{n}$ & $\%$ & n & $\%$ & $\mathbf{n}$ & $\%$ & \\
\hline $\begin{array}{l}\text { 1. Online learning is just as effective as classical } \\
\text { education. }\end{array}$ & 263 & 44.3 & 155 & 26.1 & 109 & 18.4 & 48 & 8.1 & 19 & 3.2 & $2.00 \pm 1.113$ \\
\hline $\begin{array}{l}\text { 2. Online learning is an alternative solution to the } \\
\text { problem of Education. }\end{array}$ & 123 & 20.7 & 118 & 19.9 & 146 & 24.6 & 168 & 28.3 & 39 & 6.6 & $2.80 \pm 1.239$ \\
\hline 3. I can get enough feedback on online learning. & 185 & 31.1 & 182 & 30.6 & 150 & 25.3 & 54 & 9.1 & 23 & 3.9 & $2.24 \pm 1.105$ \\
\hline 4. Online learning increases my self-confidence. & 201 & 33.8 & 184 & 31.0 & 125 & 21.0 & 62 & 10.4 & 22 & 3.7 & $2.19 \pm 1.125$ \\
\hline 5. I can communicate with lecturers in online learning. & 158 & 26.6 & 154 & 25.9 & 150 & 25.3 & 107 & 18.0 & 25 & 4.2 & $2.47 \pm 1.182$ \\
\hline 6. Online learning encourages me to research. & 160 & 26.9 & 185 & 31.1 & 121 & 20.4 & 104 & 17.5 & 24 & 4.0 & $2.41 \pm 1.172$ \\
\hline $\begin{array}{l}\text { 7. Online learning promotes university-industry } \\
\text { collaboration. }\end{array}$ & 149 & 25.1 & 148 & 24.9 & 203 & 34.2 & 72 & 12.1 & 22 & 3.7 & $2.44 \pm 1.102$ \\
\hline 10. I trust the online learning environment I get. & 124 & 20.9 & 124 & 20.9 & 184 & 31.0 & 129 & 21.7 & 33 & 5.6 & $2.70 \pm 1.182$ \\
\hline $\begin{array}{l}\text { 12. I can express my thoughts more freely in online } \\
\text { learning. }\end{array}$ & 159 & 26.8 & 195 & 32.8 & 117 & 19.7 & 88 & 14.8 & 35 & 5.9 & $2.40 \pm 1.195$ \\
\hline $\begin{array}{l}\text { 16. Online learning provides the opportunity to learn at } \\
\text { my own pace. }\end{array}$ & 142 & 23.9 & 156 & 26.3 & 168 & 28.3 & 95 & 16.0 & 33 & 5.6 & $2.53 \pm 1.176$ \\
\hline $\begin{array}{l}\text { 18. The spread of online learning is beneficial for } \\
\text { society. }\end{array}$ & 171 & 28.8 & 153 & 25.8 & 141 & 23.7 & 80 & 13.5 & 49 & 8.2 & $2.47 \pm 1.262$ \\
\hline $\begin{array}{l}\text { 20. Online learning applications should be introduced } \\
\text { in higher education }\end{array}$ & 246 & 41.4 & 142 & 23.9 & 113 & 19.0 & 60 & 10.1 & 33 & 5.6 & $2.14 \pm 1.221$ \\
\hline 22. Online learning will be inevitable in years to come. & 167 & 28.1 & 118 & 19.9 & 171 & 28.8 & 98 & 16.5 & 40 & 6.7 & $2.54 \pm 1.244$ \\
\hline 23. I recommend learning online to my friends. & 232 & 39.1 & 158 & 26.6 & 114 & 19.2 & 62 & 10.4 & 28 & 4.7 & $2.15 \pm 1.185$ \\
\hline $\begin{array}{l}\text { 24. Adequate guidance can be provided in online } \\
\text { learning. }\end{array}$ & 198 & 33.3 & 159 & 26.8 & 156 & 26.3 & 64 & 10.8 & 17 & 2.9 & $2.23 \pm 1.111$ \\
\hline 25. Online learning promotes a sense of responsibility. & 169 & 28.5 & 143 & 24.1 & 135 & 22.7 & 113 & 19.0 & 34 & 5.7 & $2.49 \pm 1.243$ \\
\hline 26. Online learning enables lifelong learning. & 217 & 36.5 & 145 & 24.4 & 131 & 22.1 & 69 & 11.6 & 32 & 5.4 & $2.25 \pm 1.215$ \\
\hline
\end{tabular}

When Table 1 is examined, proposals are given in order to get the students' opinion on the effectiveness sub-dimension of the transition of educational institutions to distance learning system in Turkey due to the epidemic. These propositions include statements about the effectiveness and efficiency of the distance learning system. The majority of the participants expressed a negative opinion on the effectiveness of the distance learning system within the framework of their responses to the propositions and the averages obtained varied from $\overline{\mathrm{x}}=2.00$ to $\overline{\mathrm{x}}=2.80$, which supported the other results.

Table 2. The distribution and averages of the statements reflecting the opinions of the students participating in the study about the sub-dimension of resistance in evaluating the distance learning system

\begin{tabular}{|c|c|c|c|c|c|c|c|c|c|c|c|}
\hline \multirow[t]{2}{*}{ Propositions of the Resistance Sub-dimension } & \multicolumn{2}{|c|}{$\begin{array}{l}\text { Strongly } \\
\text { Disagree }\end{array}$} & \multicolumn{2}{|c|}{ Disagree } & \multicolumn{2}{|c|}{ Undecided } & \multicolumn{2}{|c|}{ Agree } & \multicolumn{2}{|c|}{$\begin{array}{l}\text { Strongly } \\
\text { Agree }\end{array}$} & \multirow[t]{2}{*}{$\overline{\mathrm{x}} \pm \mathbf{S . s}$} \\
\hline & $\mathbf{n}$ & $\%$ & $\mathbf{n}$ & $\%$ & $\mathbf{n}$ & $\%$ & n & $\%$ & n & $\%$ & \\
\hline $\begin{array}{l}\text { 8. The technical problems that arise in online learning } \\
\text { make me nervous. }\end{array}$ & 47 & 7.9 & 43 & 7.2 & 63 & 10.6 & 209 & 35.2 & 232 & 39.1 & $3.90 \pm 1.221$ \\
\hline 9. Online learning undermines my social side. & 56 & 9.4 & 112 & 18.9 & 104 & 17.5 & 163 & 27.4 & 159 & 26.8 & $3.43 \pm 1.314$ \\
\hline 11. Online learning is a waste of time. & 70 & 11.8 & 161 & 27.1 & 169 & 28.5 & 97 & 16.3 & 97 & 16.3 & $2.98 \pm 1.250$ \\
\hline $\begin{array}{l}\text { 13. I quickly forget a subject I learned in online } \\
\text { learning. }\end{array}$ & 39 & 6.6 & 89 & 15.0 & 118 & 19.9 & 192 & 32.3 & 156 & 26.3 & $3.57 \pm 1.211$ \\
\hline $\begin{array}{l}\text { 14. I don't feel that I belong to the university where I } \\
\text { study. }\end{array}$ & 93 & 15.7 & 108 & 18.2 & 92 & 15.5 & 130 & 21.9 & 171 & 28.8 & $3.30 \pm 1.446$ \\
\hline 15. I get bored studying online. & 41 & 6.9 & 59 & 9.9 & 73 & 12.3 & 190 & 32.0 & 231 & 38.9 & $3.86 \pm 1.230$ \\
\hline 17. I think learning online is boring. & 35 & 5.9 & 70 & 11.8 & 97 & 16.3 & 182 & 30.6 & 210 & 35.4 & $3.78 \pm 1.213$ \\
\hline $\begin{array}{l}\text { 19. I cannot spare enough time for myself because of } \\
\text { online learning. }\end{array}$ & 71 & 12.0 & 190 & 32.0 & 170 & 28.6 & 84 & 14.1 & 79 & 13.3 & $2.85 \pm 1.205$ \\
\hline 21. Online learning negatively affects teamwork. & 25 & 4.2 & 46 & 7.7 & 76 & 12.8 & 205 & 34.5 & 242 & 40.7 & $4.00 \pm 1.107$ \\
\hline
\end{tabular}


When Table 2 is examined, suggestions are given for the students' views on the sub-level of resistance regarding the transition of educational institutions to the distance learning system in Turkey due to the epidemic. Considering the responses of the students participating in the research to the propositions; As can be understood from the percentages, it is seen that the majority of the participants regarding the distance learning system expressed negative opinions and the averages varied between $\bar{x}=2.85$ and $\bar{x}=4.00$, which supports other results.

Table 3. Comparison of the evaluations of the students who participated in the research with regard to the distance learning lessons in terms of the tools in which the lessons were followed

\begin{tabular}{|c|c|c|c|c|c|c|c|}
\hline \multicolumn{2}{|l|}{ Scale } & \multirow{2}{*}{$\begin{array}{l}\text { What devices do you follow distance } \\
\text { learning lessons from? } \\
\text { PC }\end{array}$} & \multirow{2}{*}{$\begin{array}{l}\mathbf{N} \\
152\end{array}$} & \multirow{2}{*}{$\begin{array}{l}\bar{x} \\
3.53\end{array}$} & \multirow{2}{*}{$\begin{array}{l}\text { S.s } \\
.912\end{array}$} & \multirow{2}{*}{$\begin{array}{l}\mathbf{t} \\
.326\end{array}$} & \multirow{2}{*}{$\begin{array}{l}\mathbf{p} \\
.745\end{array}$} \\
\hline distance learning & Resistance & & & & & & \\
\hline Sub-Dimensions & Dimension & Smart Phone & 442 & 3.51 & .812 & & \\
\hline & Effectiveness & $\mathrm{PC}$ & 152 & 2.38 & .971 & .043 & .963 \\
\hline & Dimension & Smart Phone & 442 & 2.37 & .856 & & \\
\hline \multirow{2}{*}{\multicolumn{2}{|c|}{ Distance Learning Overall Score }} & $\mathrm{PC}$ & 152 & 2.78 & .451 & .275 & .784 \\
\hline & & Smart Phone & 442 & 2.77 & .437 & & \\
\hline TOTAL & & & 594 & & & & \\
\hline
\end{tabular}

Note. $\mathrm{p}>0.05$.

When Table 3 is analyzed, it was found that students' evaluations regarding distance learning lessons did not differ significantly between the groups in terms of the vehicle in which the lessons were followed $(p>0.05)$.

Table 4. Comparison of the evaluations of the students involved in the study for distance learning courses and the suitability of the decision taken due to the outbreak

\begin{tabular}{|c|c|c|c|c|c|c|c|}
\hline \multicolumn{2}{|l|}{ Scale } & $\begin{array}{l}\text { Do you see the transition to distance } \\
\text { learning as an appropriate decision } \\
\text { because of the epidemic? }\end{array}$ & $\mathbf{N}$ & $\overline{\mathrm{X}}$ & S.s & $\mathbf{t}$ & $\mathbf{p}$ \\
\hline \multirow{4}{*}{$\begin{array}{l}\text { distance learning } \\
\text { Sub-Dimensions }\end{array}$} & Resistance & Yes & 309 & 3.20 & .796 & \multirow[t]{2}{*}{-10.494} & \multirow[t]{2}{*}{$.000 * * *$} \\
\hline & Dimension & No & 285 & 3.86 & .740 & & \\
\hline & Effectiveness & Yes & 309 & 2.82 & .845 & \multirow[t]{2}{*}{14.991} & \multirow[t]{2}{*}{$.000 * * *$} \\
\hline & Dimension & No & 285 & 1.90 & .648 & & \\
\hline \multirow{2}{*}{\multicolumn{2}{|c|}{ Distance Learning Overall Score }} & Yes & 309 & 2.95 & .422 & \multirow[t]{2}{*}{11.378} & \multirow[t]{2}{*}{$.000 * * *$} \\
\hline & & No & 285 & 2.58 & .373 & & \\
\hline Total & & & 594 & & & & \\
\hline
\end{tabular}

Note. $\mathrm{p}<0.001 * * *$.

When Table 4 was examined, the students who participated in the study said, "Do you see the transition to distance learning system as an appropriate decision because of the epidemic? according to their answers to the question" a significant difference was found between the groups in their assessment of distance learning system $(p<0001)$. It is observed that students who find the transition to distance learning as an appropriate decision due to the epidemic have a higher average in the lower dimension of effectiveness, while those who do not see the transition to distance learning system as a correct decision have a significantly higher average in the lower dimension of resistance. When looking at the overall average, it was found that those who stated that the transition to distance learning system was an appropriate decision had a significantly higher average.

Table 5. Comparison of the evaluations of the students taking distance learning courses according to the case of taking distance learning courses before

\begin{tabular}{|c|c|c|c|c|c|c|c|}
\hline \multicolumn{2}{|l|}{ Scale } & \multirow{2}{*}{$\begin{array}{l}\text { Have you ever studied in the } \\
\text { form of distance learning? } \\
\text { Yes }\end{array}$} & \multirow{2}{*}{$\begin{array}{l}\mathbf{N} \\
176\end{array}$} & \multirow{2}{*}{$\begin{array}{l}\overline{\mathrm{x}} \\
3.38\end{array}$} & \multirow{2}{*}{$\begin{array}{l}\text { S.s } \\
.894\end{array}$} & \multirow{2}{*}{$\begin{array}{l}\mathbf{t} \\
-2.475\end{array}$} & \multirow{2}{*}{$\begin{array}{l}p \\
.014 *\end{array}$} \\
\hline distance learning & Resistance & & & & & & \\
\hline \multirow[t]{3}{*}{ Sub-Dimensions } & Dimension & No & 418 & 3.57 & .808 & & \\
\hline & Effectiveness & Yes & 176 & 2.58 & .920 & 3.645 & $.000 * * *$ \\
\hline & Dimension & No & 418 & 2.29 & .858 & & \\
\hline \multirow{2}{*}{\multicolumn{2}{|c|}{ Distance Learning Overall Score }} & Yes & 176 & 2.86 & .436 & 3.144 & $.002 * *$ \\
\hline & & No & 418 & 2.73 & .438 & & \\
\hline Total & & & 594 & & & & \\
\hline
\end{tabular}

Note. $\mathrm{p}<0.05^{*}, \mathrm{p}<0.01^{* *}, \mathrm{p}<0.001^{* * *}$. 
When Table 5 was examined, the students who participated in the research said, "Have you previously studied using some form of distance learning?" According to their answers to the question, a significant difference was found between the groups in their assessment of the distance learning system. It was determined that the students who did not take courses with the distance learning system had a significantly higher average in the resistance dimension and the students who had previously taken courses with the distance learning system had a significantly higher average in the effectiveness sub dimension of the education system. When looking at the overall average, it was determined that the students who had previously studied with the remote education system had a significantly higher average than those who did not.

Table 6. Comparison of evaluation of distance learning courses by class variable

\begin{tabular}{|c|c|c|c|c|c|c|c|}
\hline Scale & & Class & $\mathbf{N}$ & $\overline{\mathrm{x}}$ & S.s & $\mathbf{f}$ & $\mathbf{p}$ \\
\hline \multirow[t]{8}{*}{ distance learning Sub-Dimensions } & Resistance Dimension & 1. Class & 123 & 3.54 & .842 & .550 & .648 \\
\hline & & 2. Class & 226 & 3.48 & .878 & & \\
\hline & & 3. Class & 179 & 3.49 & .787 & & \\
\hline & & 4. Class & 66 & 3.62 & .834 & & \\
\hline & Effectiveness Dimension & 1. Class & 123 & 2.34 & .881 & .121 & .948 \\
\hline & & 2. Class & 226 & 2.40 & .865 & & \\
\hline & & 3. Class & 179 & 2.37 & .895 & & \\
\hline & & 4. Class & 66 & 2.38 & .958 & & \\
\hline \multirow[t]{4}{*}{ Distance Learning Overall Score } & & 1. Class & 123 & 2.76 & .460 & .269 & .848 \\
\hline & & 2. Class & 226 & 2.77 & .406 & & \\
\hline & & 3. Class & 179 & 2.76 & .466 & & \\
\hline & & 4. Class & 66 & 2.81 & .455 & & \\
\hline Total & & & 594 & & & & \\
\hline
\end{tabular}

Note. $\mathrm{p}>0.05$.

When Table 6 was examined, it was determined that the evaluation of the students for distance learning courses according to the class variable did not differ significantly between the group $(p>0.05)$.

\section{Discussion and Conclusion}

This research was carried out to evaluate the efficiency, positive and negative aspects and missing points of the distance learning system implemented in Turkey, to continue education and training activities from the viewpoint of students due to the epidemic.

It was determined that the majority of the participants expressed negative views on the effectiveness of the distance learning system within the framework of their responses to the propositions concerning the effectiveness of the distance learning system. The result was that the distance learning system could not be as effective as classical face-to-face education and was not efficient enough. In the study conducted by Mercan (2018), it was concluded that students' belief that courses rendered in the form of distance learning can be as effective as face-to-face courses is low. In the study carried out by Koç (2020), it was determined that the student's educational environment and course study process could be controlled by the student as positive aspects of distance learning. However, the lack of feedback from the instructor, inadequate communication and interaction, and the lack of regular follow-up of the courses by the students due to the low motivation, were all negative aspects of distance learning. They found that both the educational dimension and the technical dimension of distance learning applications of students are equally important. The most frequently expressed suggestion for the development of students in the educational field is that the learning becomes interactive by adding multiple environments to the system that will increase the communication and interaction between the lecturer and the students and among the students themselves. Aktürk et al. (2008), 59\% of 53 teacher candidates reported a negative approach to web-based learning. Similarly, Balıkçığlu et al. (2019) reported that $84 \%$ of 398 students in vocational schools do not think that distance learning is an effective learning method.

Within the framework of the answers given by the students who participated in the research to the sub-dimension of resisting the distance learning system, the following results were reached; that the distance learning system weakens the social aspects of students, that students encounter unwanted technical problems arising from the system and this affects students' motivation to learn, and that they do not feel belonging to educational institutions where students study due to the distance learning system. In the research conducted by Yadigar (2010), although most of the graduate students made positive evaluations about the distance learning program, some students stated that the biggest disadvantages of distance learning is that they cannot actively participate in the learning process 
and they cannot get feedback when they face any problems.

In the question of what kind of electronic devices students follow the distance learning lessons, it is concluded that the evaluations of students towards distance learning courses do not differ significantly between the groups. Although there is no difference in the effectiveness of the system and the resistance to the system in the devices in which the students follow the distance learning lessons, it is thought that the system is compatible with mobile phones in terms of accessibility in terms of less resistance and easier access to the system in terms of students. The disadvantage most frequently voiced by university students in the research conducted by Koç (2020) was related to communication problems. More specifically, they stated that they could not get feedback from the lecturer or communicate with the instructor and their peers, which made them feel isolated. Another disadvantage most often mentioned in this category was the lack of an opportunity to get instant feedback. Similarly, many of the freshmen in Şirin's (2015) research stated that the most important negative aspect of distance learning was a lack of interaction and that they were unable to get feedback. Less than half of the students expressed opinions about technical problems. In the study conducted by Kokoç (2019), it was stated that in order to minimize the negative effects of Smart Phone addiction, Smart Phone applications should be included in the functioning in terms of educational quality in online distance learning environments.

It was determined that the students who participated in the research, who considered the transition to the distance learning system as an appropriate decision, had a more positive opinion about the efficiency of the system and had a higher average. It was also found that people who did not consider the transition to the distance learning system as a correct decision also found the system more inefficient and reported more negative opinions about the system. When looking at the general average, it was found that those who stated that the transition to the distance learning system is an appropriate decision have a significantly higher average.

It has also been determined that the students who participated in the study, who have previously studied in the form of distance learning, have a higher average in terms of the efficiency of the system than those who have never been in distance learning. Similarly, it was found that those who did not study in the form of distance learning in the sub-dimension of resisting the distance learning system stated a higher level of negative opinions about the system. When looking at the general average, it was determined that students who had previously studied with some distance learning system had a significantly higher average. In the study conducted by Boz (2019), the perceptions of distance learning of prospective teachers differ and it can be stated that the source of this difference is in favor of the computer and instructional technology education department. This shows that students' experiences of using information and communication technologies and acquiring information had a positive effect on the perception of distance learning. In this context, it may be thought that giving computer and technology lessons in the first place before the distance learning courses are given to the students in universities will have positive results for the students. In the literature, studies by Beşoluk et al. (2010) and Tatlı and Akbulut (2017) also support the results of our research.

It has been determined that students' evaluations about distance learning courses are negative, regardless of their class level, and the results did not differ significantly between the groups. As a result of the study carried out by Aras (2019) on academic staff and students in sports education institutions, it was determined that the opinions of students studying at different levels of Classes about distance learning did not differ.

Most governments around the world have temporarily closed educational institutions in an attempt to contain the spread of the covid-19 epidemic. These nationwide closures affect almost $70 \%$ of the world's student population. Several other countries are implementing localized closures affecting millions of additional learners. UNESCO countries, especially the more vulnerable and disadvantaged communities, reduce the immediate impact of school closure and provide support in their efforts to maintain the continuity of education for all through distance learning (Covid-19 Educational disruption and response, 2020). It is obvious that distance learning serves as a lifeline in such catastrophic times.

As a result, it can be said that students resisted the distance learning system, which is applied to ensure that education and training is not disrupted due to the epidemic; due the fact that they do not see it as effective as face-to-face education. However, in our study, we can say that the students who made the decision to transition to distance learning and the students who had previously received distance learning did not resist distance learning as much and that they perceive distance learning as more effective and efficient than other students. In order to avoid the possibility of such an event again, students should be provided with preliminary training on information technologies. Thus, making them ready for the distance learning system at all times. In addition, programs where distance learning courses are processed should be developed with applications suitable for both phones and other technological devices and kept ready for use. Compensatory training should be given in order for students to learn 
their lessons better when faced with this sort of situation. The ideas of the stakeholders should be taken in the studies related to distance learning and how to get more benefit from distance learning should be considered and studies should be done accordingly. In his study, Rose et al. (2020) argued that the activities put into practice during this epidemic period should be applied by using the experience of the academic education community and practical solutions should be applied, and forward-looking scientific approaches should be given priority. Arslan (2019) suggests that distance learning opportunities should be well evaluated for future educational transformation. As well as infrastructure development, the evaluation of distance learning practices by taking into account the views and suggestions of their stakeholders will contribute positively to the quality and efficiency of Education. With this study, it is thought that the evaluation of the opinions of the distance learning students, which constitute the biggest volume among the stakeholders, will increase the efficiency of distance learning applications, and it is thought that conducting studies for the teaching staff and other staff will also increase the efficiency of distance learning applications.

\section{References}

Aktürk, A. O., Şahin, İ., \& Sünbül, A. M. (2008). Computer teacher candidates' attitudes towards web-based teaching. Paper presented at the 8th International Educational Technologies Conference, 6-9 May 2008. Anatolian University. Eskisehir.

Aras, E. (2019). Examination of the academic staff working in sports education institutions and the opinions of students studying sports in distance learning. Master Thesis. Frrat University, Institute of Health Sciences, Elaziğ.

Arslan, V. (2019). Web-based distance learning experience and productivity analysis: the case of Istanbul University. Master Thesis. Istanbul University, Institute of Science, Istanbul.

Balıkçıŏglu, N., Çınar-Öz, D., \& Işın, N. N. (2019). Satisfaction research in distance learning courses of university students: the case of Așı Veysel Vocational School. C.Ü Journal of Economic and Administrative Sciences, 20(1), 462-473.

Begimbetova, K. (2015). Satisfaction level of faculty and students in distance learning. Master's Thesis. Gazi University, Ankara.

Beşoluk, Ş., Kurbanoğlu, N. İ., \& Önder, İ. (2010). Educational technology usage of preservice and in-service science and technology teachers. Elementary Education Online, 9(1), 389-395.

Boz, A. (2019). Examination of distance learning perceptions in the context of technology acceptance and use of teachers candidates. Master Thesis. Necmettin Erbakan University, Institute of Educational Sciences, Konya.

Çakır, G., \& Yurtsever, B. (2012). An implementation of distance learning program for teaching common necessary courses in formal education: Karabük University sample. Procedia-Social and Behavioral Sciences, 55, 187-195. https://doi.org/10.1016/j.sbspro.2012.09.493

Doğan, S., \& Tatık, R. Ş. (2015). Evaluation of distance learning program in Marmara University according to the views of students. Route Educational and Social Science Journal, 2(1), 247-261. https://doi.org/10.17121/ressjournal.187

Donmuş-Kaya, V. (2018). The impact of the online learning environment based on the model of teaching activities on students' academic achievements, attitudes and persistence in learning. $\mathrm{PhD}$ Thesis. Firat University, Institute of Educational Sciences, Elazığ.

Ekmekçi, E. (2015). Distance learning in foreign language teaching: evaluations from the perspectives of freshman students. Procedia-Social and Behavioral Sciences, 176, 390-397. https://doi.org/10.1016/j.sbspro.2015.01.487

Erdoğan, Y., Bayram, S., \& Deniz, L. (2007). Web-based teaching attitude scale: a study of explanatory and confirmatory factor analysis. International Journal of Human Sciences, 4(2), 1-14.

Ertürk, S. (1973). Program development in education. Yelkentepe Publications: Ankara.

Higher Education Institution. (2020). Description of distance learning to be implemented in universities. Retrieved May 2, 2020, from https://www.yok.gov.tr/Sayfalar/Haberler/2020

İçten, T. (2006). Development of web-based online exam system application for distance learning students. Master's Thesis. Gazi University, Graduate School of Natural and Applied Sciences, Ankara.

İliniş, Ç. (2006). An evaluation of on-line- language course at Adana Vocational School of Çukurova University. 
Master's Thesis. Çukurova University, Adana.

Karakeçili, V. (2019). Comparison of attitudes of $Y$ and $Z$ generations towards online education technologies. Master's Thesis. Bahçeşehir University, Institute of Educational Sciences, Istanbul.

Koç, E. M. (2020). Views of students in higher education on distance learning: advantages, disadvantages, problems encountered and recommendations. Turkish Studies-Applied Sciences, 15(1), 85-108.

Kokoç, M. (2019). Modeling the relationship of distance learning students' commitment levels with smartphone dependencies, self-regulation, and self-sufficiency skills. $\mathrm{PhD}$ Thesis. Atatürk University, Institute of Educational Sciences, Erzurum.

Mercan, A. (2018). University students' opinions about distance learning and their readiness: an example of the Faculty of Arts and Sciences of the University. Master's Thesis. Afyon Kocatepe University Institute of Social Sciences, Afyon.

Miser, R. (2002). Adult education in a globalized world. Ankara University. Journal of Faculty of Educational Sciences, 35(1), 55-60.

Orhan, A. (2016). Evaluation of foreign language course curriculum with context, input, process and product (CIPP) model. Master's Thesis. Düzce University, Düzce.

Osborne, J. W., \& Amy, O. (2004). The power of outliers and why researchers should always check for them. Practical Assessment, Research \& Evaluation, 9(6).

Rose, S., \& Msed, M. D. (2020). Medical student education in the time of Covld-19. American Medical Association, Published Online: March 31, 2020. https://doi.org/10.1001/jama.2020.5227

Shao, A. T. (2002). Marketing research: An aid to decision making, cincinnati. South-Western/Thomson Learning: Ohio.

Şirin, R., \& Tekdal, M. (2015). Student views on distance learning of English course. Gaziantep University Journal of Social Sciences, 14(1), 323-335. https://doi.org/10.21547/jss.256783

Sönmez, V. (1991). Philosophy of Education. Adam Publishing: Ankara.

T. R. Ministry of Health. (2020). Covid-19 New coronavirus disease. Retrieved May 2, 2020, from https://covid19bilgi.saglik.gov.tr/tr/covid-19-what is new-koronavirus-hastaligi

Tatlı, Z., \& Akbulut, H. İ. (2017). Öğretmen adaylarının alanda teknoloji kullanımına yönelik yeterlilikleri. Ege Eğitim Dergisi, 1(18), 31-55. https://doi.org/10.12984/egeefd.328375

Unesco. (2020). Covid-19 Educational Disruption and Response. Retrieved May 15, 2020, from https://en.unesco.org/covid19/educationresponse

Yadigar, G. (2010). Evaluation of the effectiveness of distance learning programs Example of Gazi University. Master Thesis. Gazi University, Ankara.

\section{Copyrights}

Copyright for this article is retained by the author, with first publication rights granted to the journal.

This is an open-access article distributed under the terms and conditions of the Creative Commons Attribution license (http://creativecommons.org/licenses/by/4.0/). 